\title{
KEY TO DIACRITICAL MARKS ${ }^{\circ}$
}

\section{THE ALPHABET}

My vocabularies are written, so far as possible, in simple phonetic English. The words are divided into syllables separated by hyphens. The accented syllable is marked with the acute accent (').

I. Sounds that have a fixed and definite value in English, like our words pin, peg, hat, not, and so on, are pronounced exactly as in English. In such syllables diacritical marks are unnecessary and as a rule are omitted.

2. Sounds represented in English by a double consonant, or by a syllable the pronunciation of which is not phonetic, are always spelled phonetically. Thus the sounds represented by our words all and who are written $a w l$ and hoo.

3. Unmarked vowels, except in syllables having a fixed value like those mentioned in section I, have the usual long or pure sound given them in the English alphabet.

4. An unmarked vowel standing alone (as a syllable or word) always takes its long or pure alphabetic sound.

\section{Key to Vowel Sounds, Diacritical Marks, and so on}

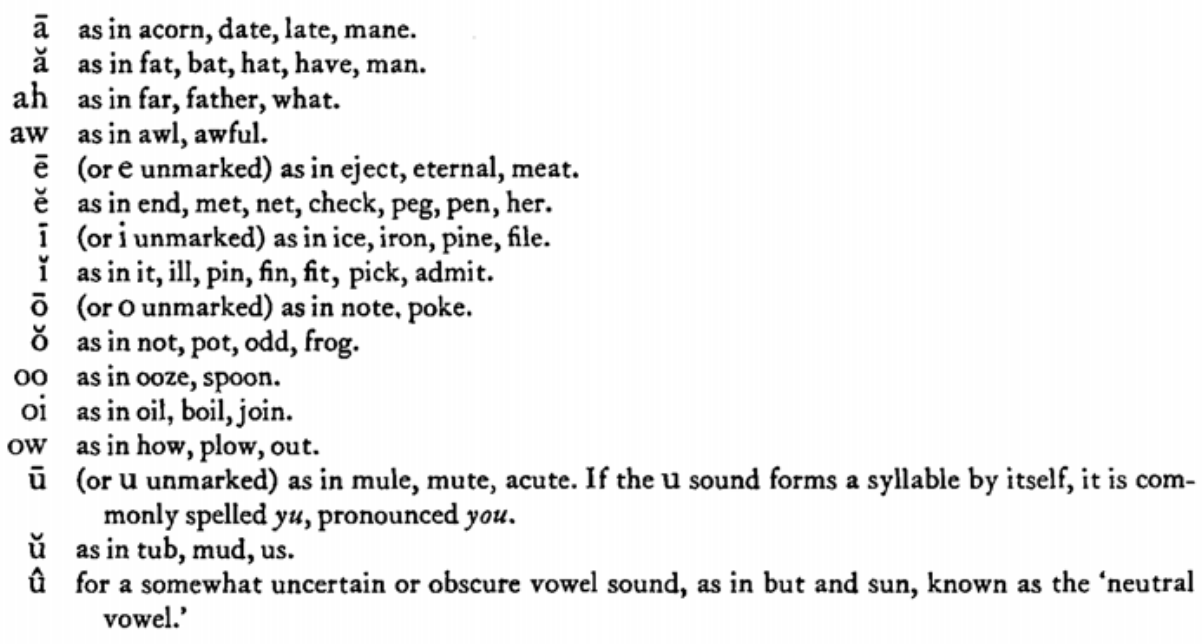

Prolonged vowels are indicated by doubling the letter (as aa, ee, \&c.)

Prolonged or trilled consonants are indicated by a double acute accent (").

The consonants, except c, g, and q, have their ordinary English values; $\mathrm{c}$ and $\mathrm{g}$ having in English both hard and soft sounds, require special treatment, $\mathrm{q}$ is not used. The $\mathrm{q}$ sound occurs only before $\mathrm{u}$, and is better represented by $\mathrm{kw}$ (kween instead of queen).

* This statement reproduces the first page of Dr. Merriam's printed vocabulary forms.

Dr. Merriam's views on phonetic transcription are outlined in his paper, The Classification and Distribution of the Pit River Indians of California, Smithsonian Misc. Colls., Vol. 78, No. 3 (Publ. 2784), 1926.-Ed. 
$\mathrm{c}$ is never used except before $\mathrm{h}$, as in chin, chum, chap, church. It is commonly preceded by $\mathrm{t}$ to render the pronounciation more correct. Hence the usual combination is $t c h$, as in hatch.

$\mathrm{g}$ is always hard, as in get, give, grind.

$\mathrm{j}$ is always soft, as in jet, jam, jelly, judge.

$\mathrm{k}$ has its usual value, as in kill, keep, king. It is also used instead of $\mathrm{c}$ for the hard sound of $\mathrm{c}$ in our words cat, cow, come, cold, cream, clinic, and the like.

$\mathrm{s}$ has its usual sound, as in see, sink, soft, \&c, and is also used instead of $\mathrm{c}$ for the soft sound of $\mathrm{c}$ in our words cent, cinder, mice.

ah (super) has the soft sound as in german ach, büch, \&c. (In MS written th).

n (super) is nasalized, and follows a nasalized vowel, as $0^{n}$. (In MS written $\mathrm{g}$ ).

An apostrophe (') after a vowel followed by another letter gives the long sound to the vowel, and may also indicate an omitted or silent letter.

An apostrophe (') at either end of a syllable calls for an exploded sound.

An exclamation (!) after a letter indicates that the letter is stressed.

\title{
BIBLIOGRAPHICAL ABBREVIATIONS
}

\author{
AA \\ American Anthropologist \\ BAE \\ Bureau of American Ethnology \\ -B Bulletin \\ -R Annual Reports \\ UC-PAAE University of California Publications in \\ American Archaeology and Ethnology
}

